\title{
SUKUT AL-SYÂRI DALAM PERSPEKTIF IMAM AL-SYATHIBY DAN KEHUJJAHANNYA DALAM IJTIHAD
}

\author{
Al Ikhlas, Riza Wardevi, dan Rahmi Wiza \\ Universitas Negeri Padang \\ Jl. Prof. Dr. Hamka Air Tawar Padang \\ e-mail: rizawardevi@fis.unp.ac.id, rahmiwiza@fis.unp.ac.id
}

\begin{abstract}
Islam is a perfect religion and there is no Samawi religion after Islam. All laws are derived from alShari (Allab Swt) and this has covered all forms of human behavior. All these provisions are revealed to the Prophet Muhammad PBUH. So this makes Rasulullah PBUH as the main source in teaching syari 'at. However, after Rasulullah PBUH past away there is no more revelations that come down to humans. This is the problem among Muslims. On that basis, Imam al-Syathiby gave birth to the concept of sukut al-Syari' as one method of ijtihad in answering the absence of legal proof in Islam.
\end{abstract}

Kata kunci: sukut al-syari, Imam al-Syathiby, maqashid al-syari ah

\section{PENDAHULUAN}

I slam merupakan ajaran Samâwy kepada Rasulullah Saw. Adapun yang menjadi tujuan utama diturunkannya Islam adalah untuk mewujudkan kemashlahatan bagi seluruh umat manusia. Kemashlahatan tersebut berupa kebahagiaan dan juga ketentraman serta menolak segala bentuk keburukan berupa kesengsaraan dan kebinasaan dalam kehidupan manusia selama hidup di dunia dan juga di akhirat nantinya.

Agar terwujudnya kemashlahatan tersebut, Allah Swt mensyariatkan seperangkat hukum dalam bidang akidah, muamalah dan akhlak. Allah Swt menegaskan bahwa seluruh hukum tersebut telah dijelaskan dalam Alquran dan Sunnah. Sebab yang berhak dalam menetapkan hukum hanyalah Allah Swt. Oleh sebab itu, tidak dipahami adanya kekosongan dalil pada setiap tindak tanduk manusia karena semuanya telah diatur oleh Allah Swt.

Namun, setelah meninggalnya Rasulullah Saw maka terputuslah penyampaian wahyu dari langit. Sebab yang diberi mandat oleh Allah Swt dalam mentransformasikan firman-Nya kepada manusia hanyalah Rasulullah Saw. Oleh sebab itu, tidak mungkin kita berharap lagi kepada wahyu yang akan diturunkan. Dengan meninggalnya Rasulullah Saw maka terputuslah perkataan Allah Swt untuk manusia.

Lalu, yang menjadi problema adalah bagaimana dengan perbuatan manusia yang tidak memiliki keterangan hukum yang muncul setelah masa kenabian. Sebab tidak ada lagi seorangpun yang mampu untuk menyampaikan firman Allah Swt karena tidak akan ada lagi nabi dan rasul setelah Muhammad Saw. Hal 
inilah yang memunculkan kaidah bahwa wahyu bersifat terbatas sedangkan perbuatan manusia akan terus berkembang.

Maka, untuk menjawab tantangan ini ulama melakukan ijtihad. Imam alSyathiby memunculkan sebuah istilah yang dikenal dengan sukut al-Syâri. Ia menjadikan hal ini sebagai salah satu cara dalam menyibak tirai maqashid al-syari ah dalam rangka mencari kepastian hukum. Meskipun demikian, apa yang dimaksud dengan konsep sukut al-Syâri dan bagaimanakah kehujjahannya? Dalam tulisan ini penulis akan memaparkanya kepada para pembaca. Semoga bermanfaat.

\section{PENGERTIAN SUKUT AL-SYARI}

Secara bahasa al-sukût (السُّكوثُ) merupakan bentuk mashdar dari kata سَكَتَ

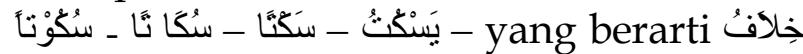
النُطق النق

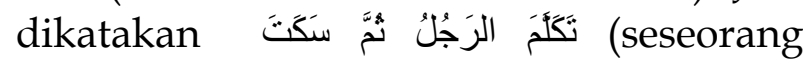
berkata dan ia kemudian diam) maka maksudnya adalah انِقطاعَ عَنْ الكَلاجٍ (ia berhenti dari berbicara) (Ibnu Manzhur, 1992: (IV) 303).

$$
\text { Adapun kata al-Syâri' (الثَّارعُ }
$$
merupakan bentuk ismu al-fầil (kata yang

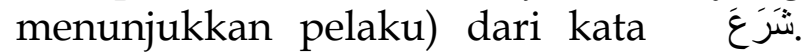

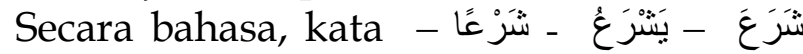

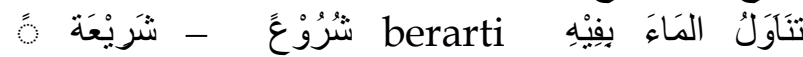
(meminum air dengan mulutnya). Adapun yang dimaksud dengan al-Syâri adalah Allah Swt sebab Dia-lah yang memiliki hak dan menetapkan hukum bagi manusia. Dalam sebuah ungkapan disebutkan:

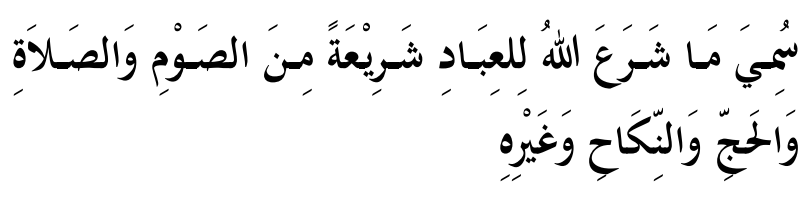

Artinya: Segala yang ditetapkan oleh Allah Swt bagi manusia dinamakan dengan syari at berupa perintah untuk berpuasa, shalat, haji, nikah serta hukum-hukum lainya. (Ibnu Manzhur, 1992: (II) 270).

Jika dua kata ini digabung, secara harfiyah dapat dipahami bahwa yang dimaksud sukût al-Syâri adalah tidak adanya keterangan berupa wahyu dari Allah Swt untuk menjelaskan status hukum bagi sebagian perbuatan manusia. Khususnya pada perbuatan manusia yang muncul setelah kenabian. Sebab segala hukum dalam Islam merupakan hasil pemahaman ulama terhadap perkataan Allah Swt.

Ulama sepakat bahwa seluruh perbuatan manusia mesti memiliki petunjuk dari Allah Swt dan tidak boleh melampaui dari petunjuk tersebut. Dengan demikian ulama mendefinisikan hukum dengan:

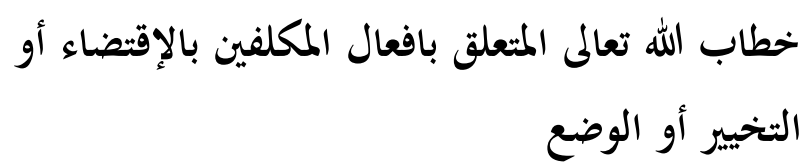

Artinya: "Khitâb (perkataan) Allah SWT yang berkaitan dengan perbuatan mukallaf (bersifat) tuntutan atau pilihan atau wadha' (sesuatu yang dapat mempengaruhi hukum yang lain). (Tajuddin al-Subki, 1999: 482).

Oleh sebab itu, perbuatan manusia mesti sesuai dengan ketentuan hukum dari Allah Swt. Jika tidak keterangan dari Allah Swt maka hal inilah yang dikenal dengan sukût al-Syâri . 


\section{SUIKUT AL-SYARI DALAM PERSPEKTIF IMAM AL-SYATHIBY}

\section{Biografi Singkat Imam al-Syathiby}

Nama lengkapnya adalah Ibrâhim bin Mûsa bin Muhammad al-Lakhmy alGharnâthy yang kemudian lebih populer dengan al-Syâthiby. (Hammadi al-Ubaidy, 1996: 11). Ia digelari dengan Abu Ishâq yang mana Ishaq merupakan nama dari salah seorang anaknya. Nenek moyang Imam al-Syâthiby berasal dari suku Lakhmu (Abu Sa`ad al-Sam`any, 1984: (XI) 18) sehingga ia di-nisbah-kan dengan alLakhmy. Adapun dengan al-Syâthiby karena kampung asal orang tuanya adalah Syâthibah (Syihabuddin al-Baghdady, 1997: (III) 309) dan dengan al-Gharnâthy karena ia tumbuh besar dan meninggal di Gharnâthah. Oleh sebab itu, pada sebagian referensi terkadang penyebutan gelar al-Gharnâty lebih populer dari pada al-Syâthiby.

Ulama ataupun sejarawan berbeda pendapat dalam memperkirakan tahun kelahiran Imam al-Syâthiby. Sebab ia sendiri tidak pernah menyebutkan tahun kelahirannya pada karya-karyanya. Menurut Muhammad Abu al-Ajfan dalam pengantar karyanya Min Atsâri Fuqahâ' alAndalus; Tahqiq Fatâwa al-Syâthiby mengatakan bahwa Imam al-Syâthiby lahir pada tahun $720 \mathrm{H}$. Pendapat ini didasarkan kepada argumen bahwa gurunya; Abu Ja`far Ahmad bin al-Ziyât meninggal pada tahun $728 \mathrm{H}$. Ketika ia meninggal Imam al-Syâthiby merupakan seorang remaja yang penuh semangat dalam menuntut ilmu kepadanya. (Muhammad al-Ajfan, 1985: 32).

Namun, sebuah pendapat berbeda yang disampaikan oleh Hammâdy al-
Ubaidy bahwa tahun kelahiran Imam alSyâthiby bukan $720 \mathrm{H}$, akan tetapi $730 \mathrm{H}$. Pendapat ini didasarkan kepada argumen bahwa Imam al-Syâthiby merupakan teman dari penyair Ibnu Zamrak yang dilahirkan pada tahun $733 \mathrm{H}$. Di samping itu, pernyataan Imam al-Syâthiby yang dikutip oleh Hammâdi al-Ubaidy mengatakan bahwa pada tahun $735 \mathrm{H}$ ia masih anak-anak yang belajar kepada gurunya Ibnu al-Fakhkhar al-Bairy yang sangat salut dengan kecerdasannya dan begitu juga dengan kemampuannya dalam memecahkan beberapa permasalahan dalam Bahasa Arab dengan pemecahan yang tidak terpikirkan oleh yang lain. (Hammady al-Ubaidy, 1995: 12).

Menyikapi perbedaan ini, penulis lebih cendrung kepada pendapat yang menyatakan bahwa Imam al-Syâthiby lahir pada tahun 730 H. Sebab, Lisanuddin al-Khâtib menyebutkan Imam al-Syâthiby bukanlah murid dari al-Ziyât, jadi mereka tidak pernah bertemu. AlZiyât merupakan penduduk Malaqah (Malaga) yang sering mengunjungi Gharnâthah untuk berceramah di berbagai majelis ilmu. (Lisanuddin alKhatib, 1973: 287).

Mayoritas ulama dan sejarawan sepakat mengatakan bahwa Imam alSyâthiby meninggal pada tahun $790 \mathrm{H}$. Muridnya yang bernama 'Imâd menulis pada pembukaan kitab al-Muwâfaqât yang dikomentarinya bahwa Imam al-Syâthiby meninggal pada tanggal 8 Sya ban $790 \mathrm{H}$ /1388 M. Dapat diperkirakan bahwa umur Imam al-Syâthiby lebih kurang 70 tahun.(Hammady al-Ubaidy, 1996: 13). 


\section{Sukut al-Syari Menurut Perspektif Imam al- Syathiby}

Sukût al-Syâri merupakan sebuah istilah yang dimunculkan dari pemahaman terhadap ungkapan Imam al-Syâthiby tentang cara mengetahui maqshad alSyâri oleh kelompok al-Rasikhûna fi al-Ilmi. (Imam al-Syathiby, 2003: (II) 293). Menurut Imam al-Syâthiby, ada empat cara yang digunakan oleh kelompok ini untuk mengetahui maqshad al-Syâri, yaitu: Pertama, mujarradu al-amri wa al-nahyi alibtid'ai al-tashrîhy (kemurnian perintah dan larangan pada permulaan lagi jelas). Kedua, itibâru 'ilali fi al-amri wa al-nahyi (keberadaan illah pada perintah dan larangan). Ketiga, annâ li al-Syâri fi syar ‘ al-ahkâmi al-'âdiyah wa al- ibâdiyah maqâshid al-ashliyah wa maqâshid al-tâbi ah (Bahwa Allah Swt dalam menjelaskan hukumhukum yang berkaitan dengan 'âdah dan ibadah memiliki tujuan utama dan tujuan pengikut).

Keempat,

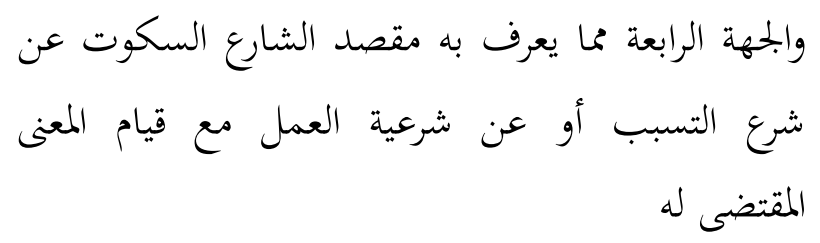

Cara yang keempat dalam mengetahui maqshad al-Syâri adalah dengan diam (tidak ada keterangan berupa nash yang bersifat juz`i) atas sebab lahirnya (hukum) atau (tidak adanya dalil yang menjelaskan) pensyariatan hukum meski adanya makna yang menuntut lahirnya hukum."(Imam al-Syathiby, 2003: (II) 293)

Dari ungkapan di atas, Imam alSyâthiby tidak menyebutkan secara terang ungkapan sukût al-Syâri. Namun istilah ini dapat dipahami keberadaannya dari penunjukan makna ungkapan di atas bahwa yang dimaksud dengan sukût alSyâri adalah diam ataupun tidak adanya penjelasan hukum syara' (Muhammad Bakar, 1427 H: 198) berupa dalil juz'i yang jelas dan terang dari al-Syâri (Allah Swt) untuk mensyariatkan sebuah hukum yang berkenaan dengan perbuatan mukallaf dengan memberikan status hukum tertentu. Ketiadaan dalil untuk penunjukkan hukum atas perbuatan ini dapat ditemukan dalam aspek ibadah, muamalah dan `adah.

Dalam syari at Islam, yang memiliki otoritas mutlak dalam menetapkan hukum hanya Allah Swt. Hal ini menjadi akidah yang wajib diyakini oleh setiap umat Islam. Dalam al-Qur'an Allah Swt berfirman:

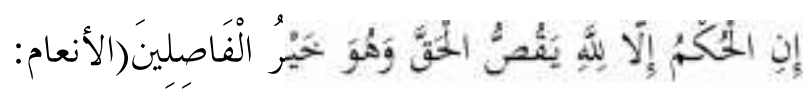

Sesungguhnya (yang) menetapkan hukum itu hanyalah hak Allah. Dia menerangkan yang sebenarnya dan Dia pemberi keputusan yang paling baik. (Q.S. AlAn`am [6]: 57)

Imam al-Marâghy menjelaskan hukum yang dimaksudkan pada ayat di atas adalah hukum yang mengatur tentang segala urusan umat manusia. Untuk menentukan dan menetapkan hukum tersebut mutlak atas kehendak Allah Swt. Sebab segala hukum yang ditetapkan Allah Swt syarat dengan hikmah dan nilai. Oleh karena itu tidak ada yang akan mendahului ataupun melampaui batasan yang telah ditentukan-Nya. (Ahmad al-Maraghy, 1946: (VII) 142).

Syari'at yang diturunkan oleh Allah Swt telah sempurna, artinya tidak akan ada lagi penambahan ataupun pengurangan 
pada ushûl ataupun furu' syariat itu sendiri semenjak wafatnya Rasulullah SAW hingga ke akhir zaman. Hal ini ditegaskan dalam wahyu yang disampaikan Jibril a.s. kepada Rasulullah Saw pada peristiwa haji Wada'. Allah Swt berfirman:

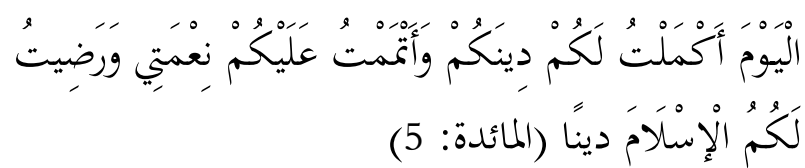

Pada hari ini telah Kusempurnakan untuk kamu agamamu, dan telahKu-cukupkan kepadamu nikmat-Ku, dan telah Ku-ridhai Islam itu jadi agama bagimu. (Q.S. AlMaidah [5]: 3)

Kesempurnaan syari at Islam yang diturunkan oleh Allah SWT juga ditegaskan dalam firman-Nya yang lain:

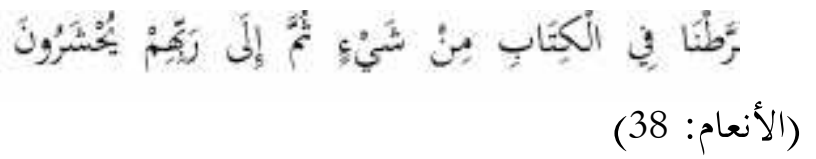

Tiadalah Kami alpakan sesuatupun dalam Al-Kitab, kemudian kepada Tuhanlah mereka dihimpunkan." (Q.S. Al-An`am [6]: 38)

Imam al-Qurthuby menjelaskan bahwa tidaklah Allah Swt meninggalkan ataupun mendiamkan sesuatu kecuali telah disebutkan dalam Alquran. Penyebutan tersebut bisa saja bersifat jelas dan terperinci sehingga tidak meragukan dalam pemahaman. Akan tetapi ada juga yang bersifat umum dan global sehingga memungkinkan lahirnya berbagai pemahaman. Oleh sebab itu, untuk penyebutan yang bersifat global ini kemudian dijelaskan dalam Sunnah Rasulullah Saw (baik berupa perkataan, perbuatan ataupun ketetapan). Begitu juga dengan metode lain yang disepakati ulama berupa Ijma' dan Qiyas. Namun, semua metode ini memiliki kaitan dengan teks-teks Alquran dan tidak bisa dipisahkan. (Muhammad al-Qurthuby, 2006: (IX) 371).

Sepeninggal Rasulullah Saw tidak ada lagi seorangpun yang mampu memberikan penjelasan hukum terhadap permalahan yang terus berkembang. Maka, untuk menjawab permasalahan ini, Imam al-Syâthiby melahirkan konsep sukûtal-Syâri sebagai kesimpulan atas pengamatannya terhadap kelompok alrasikhûna fi al-ïlmi untuk menjelaskan status hukum dari perbuatan yang didiamkan oleh Allah Swt dengan melakukan pendekatan maqâshid alsyari ah al-Islâmiyah.

Imam al-Syâthiby tidak menyamakan seluruh bentuk perbuatan manusia yang tidak memiliki penjelasan hukum secara jelas dan terang dari Allah Swt. Oleh sebab itu, ia berupaya untuk memilah dan memilih perkara yang bisa dikembangkan hukumnya dan mana yang tidak bisa sama sekali. Sebab, secara umum, hukumhukum Islam terbagi kepada dua bentuk, yaitu: tsawâbit (otentik) yaitu hukumhukum yang tidak ada lagi peluang ijtihâd padanya dan mutaghayyirât (kontekstual) yaitu hukum-hukum yang memiliki peluang untuk ijtihaâd padanya.

Inilah yang dimaksud dengan konsep sukût al-Syâri oleh Imam alSyâthiby, yaitu ketiadaan dalil yang bersifat juz $i$ menjelaskan status hukum perbuatan manusia baik berupa nash ataupun keterangan langsung dari Rasulullah Saw. Adapun fungsi sukût alSyâri sebagi salah satu cara dalam mengetahui maqshad al-Syâri akan 
dijelaskan secara rinci dalam pembagian sukût al-Syâri dan kehujjahannya.

\section{Pembagian Sukût al-Syâri dan Kehujjahannya}

Dalam al-Muwâfaqât, Imam alSyâthiby membagi sukût al-Syâri kepada dua bentuk. Masing-masing bentuk memiliki kadar kehujjahan yang berbeda. Oleh sebab itu dalam pembahasan ini, penulis akan menjelaskan masing-masing pembagian dari sukût al-Syâri serta kehujjahan masing-masingnya dari pandangan Imam al-Syâthiby dalam mengisthinbatkan hukum. Pembagian tersebut adalah: pertama, sukv̂t al-Syâri dalam bidang Mu`amalah. Kedua, sukût alSyâri` dalam bidang Ibadah.

1. Sukît al-Syâri dalam Bidang Mu`amalah

أحدهما أن يسكت عنه لأنه لا داعية له تقتضيه ولا موجب يقدر لأجله, كالنوازل التي حدثت بعد رسول الله

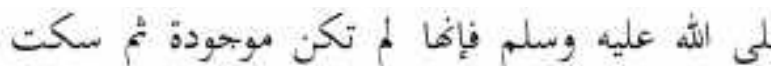
عنها مع وجوده, و إنما حدثت بعد ذلك, فاحتاج أهل الشريعة إلى النظر فيها و إجرائها على ما تقرر فن كليتها, وما أحدثه السلف الصالح راجع إلى هذا القسم, كجمع المصحف و تلوين العلم, و تضمين الصناع وما أشبه ذالك محا لم يجر له في زمان رسول الله صلى الله عليه وسسلم وفم تكي من نوازل زمانه ولا عرض للعمل يها مو جب يقتضيها فهذا القسم جارية فروعه على أصوله المقررة شرعا بالا إشكال فالمقصد الشرعي فيها معروف من الجهات المذكورة قبل.

Bentuk yang pertama, (Allah Swt) mendiamkan (hukum)nya karena tidak ada hal yang menuntut (lahirnya hukum) atau makna yang menentukan sebuah (hukum). Seperti kejadian yang terjadi setelah meninggalnya Rasulullah Saw. Permasalahan seperti ini tidak ada (pada masa Rasulullah Saw) kemudian (Allah Swt) diam ketika permasalahan itu ada karena ia muncul setelah masa Rasulullah Saw. Ahlu alSyari ah (ulama) berupaya untuk mencarikan hujjah pada permasalahan tersebut dengan mengembalikannya kepada keglobalan nilainilai ajaran (Islam). Sebagaimana ulama terdahulu melakukannya dengan mengembalikannya kepada (keglobalan ajaran). Seperti pengumpulan Alquran, penulisan ilmu ke bentuk buku, memberikan jaminan pada pemesanan barang dan berbagai bentuk perbuatan lain yang tidak disebutkan (hukumnya) ataupun tidak ditemukan kejadiannya ataupun tidak ada tuntutan yang menghendaki lahirnya hukum. Namun, yang pasti permasalahan furu seperti ini sejalan dengan ushûl-nya. Maka yang menjadi maqshad al-syar $i$ dalam bentuk ini dapat diketahui dalam bentuk sebelumnya. (Imam al-Syathiby, 2003: (II) 311).

Dalam bentuk yang pertama ini, Imam al-Syâthiby menjelaskan bahwa sebagian dari perbuatan manusia tidak memiliki keterangan hukum berupa nash ataupun penjelasan dari Rasulullah Saw berupa keterangan langsung yang menunjuk kepada hukum tertentu atau makna-makna tertentu yang bersumber dari Rasulullah Saw meskipun belum menghendaki lahirnya hukum tertentu ketika itu.

Imam al-Syâthiby juga menegaskan bahwa terjadinya kekosongan hukum atas sebagian perbuatan itu disebabkan oleh munculnya permasalahan-permasalahan ini setelah masa kenabian Muhammad Saw. Sehingga tidak seorang pun yang mampu memberikan penjelasan yang 
tepat sesuai dengan kehendak al-Syâri karena terputusnya wahyu dari Allah Swt.

Selanjutnya, Imam al-Syâthiby menyebutkan bahwa dalam usaha mencarikan hukum dari bentuk ini, para ulama klasik berupaya untuk mengembalikannya kepada keglobalan nilai-nilai ajaran Islam atau yang disebut dengan al-adillah al-kulliyah. Di antara bentuk perbuatan yang mereka kembalikan kepada keglobalan nilai-nilai tersebut adalah, mengumpulkan Alquran ke dalam satu mushhaf, penulisan ilmu ke dalam bentuk buku dan memberikan jaminan pada akad pemesanan barang.

Di antara contoh yang dipaparkan oleh Imam al-Syâthiby dalam alMuwâfaqât adalah pengumpulan Alquran, penulisan ilmu ke dalam bentuk lembaran-lembaran buku dan kebolehan untuk memberikan jaminan pada akad pemesanan barang (Imam al-Syathiby, 2003: (II) 311).

Dari beberapa contoh yang dipaparkan di atas memberikan isyarat bahwa perbuatan mukallaf yang bisa dikembangkan hukumnya dengan cara ini adalah perbuatan yang berkaitan dengan mu`amalah. Adapun yang dimaksud dengan mua`malah adalah setiap perbuatan ataupun tindak tanduk manusia yang berhubungan dengan sesama manusia. Sebab dibalik ketentuan hukum yang disyariatkan, yang diiginkan oleh Allah Swt adalah kemudahan bagi manusia.

2. Suk̂̂t al-Syâri dalam Bidang Ibadah

$$
\text { حكم عند نزول النازلة زائد على منه و موجبه المقتضى له قائم, فلم يقرر فيه في ذلك الزمان, }
$$

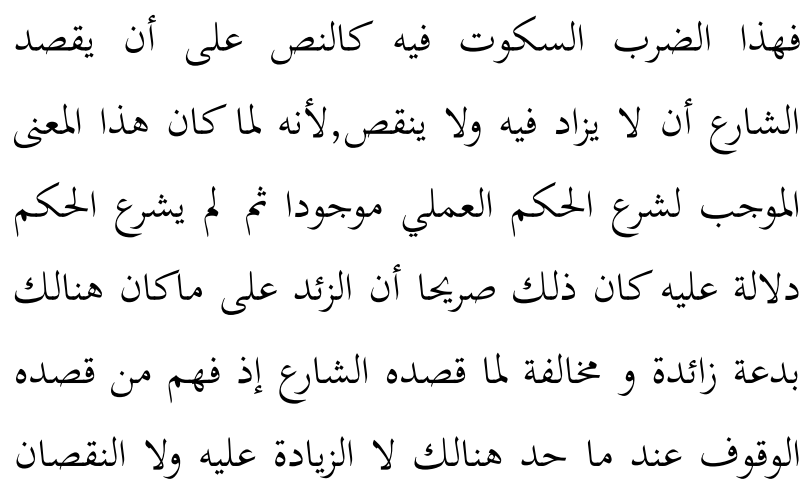

Al-Syâri mendiamkan sebuah permasalahan meskipun ada hal yang dapat menghendaki lahirnya keterangan hukum. Tidak ada (juga) ketetapan hukum ketika terjadinya sebuah perbuatan pada masa itu (masa Rasulullah Saw). Maka diam dalam bentuk ini seperti nash yang diinginkan oleh alSyâri tidak ada penambahan ataupun pengurangan padanya. Sebab ketika ada makna yang bisa menghendaki lahirnya sebuah hukum akan tetapi tidak ada keterangan lebih lanjut dari nash untuk menjelaskan status hukumya maka yang demikian dinamakan dengan bid'ah dan menyalahi apa yang menjadi maqshad dari al-Syâri. yang dipahami dari maqshad di sini adalah berhenti pada batas yang telah ditentukan dengan tidak melakukan penambahan dan juga pengurangan (dari apa yang telah dijelaskan dalam nash) (Imam al-Syathiby, 2003: (II) 311).

Pada bentuk yang ke dua ini, Imam al-Syathiby menjelaskan bahwa diam alSyâri tentang hukum sebuah perbuatan pada masa Rasulullah Saw meskipun adanya makna yang menuntut lahirnya hukum atas perbuatan tesebut. Akan tetapi tidak ditemukan ketetapan hukum berupa dalil (dari al-Syâri') yang menetapkan hukumnya. Pembagian sukut 
seperti ini adalah nash yang diinginkan oleh al-Syâri tidak adanya penambahan ataupun pengurangan.

Sebab ketika adanya makna yang menuntut lahirnya sebuah hukum atas sebuah perbuatan akan tetapi tidak di temukan adanya dalil khusus yang menjelaskan hukum tersebut. Maka dengan jelas, penambahan seperti ini dinamakan dengan bid ah dan bertentangan dengan qashdu al-Syâri. Hal yang dapat dipahami dari qashdu al-Syâri di sini adalah berhenti pada batasan yang telah ditentukan dan tidak boleh adanya penambahan ataupun pengurangan dari batasan yang telah ditentukan.

Jika diteliti lebih dalam, pembagian sukût al-Syâri dalam bentuk ini oleh Imam al-Syâthiby mengarah kepada ranah ibadah bukan ranah mu'amalah dan 'adah. Hal ini dapat diketahui dari beberapa contoh yang ia paparkan, di antaranya: sujud syukur dalam mazhab Malikiyah dinilai bid ah karena tidak ada dalil yang membolehkannya secara ekplisit. Begitu juga dengan melakukan do`a bersama setelah selesai shalat dan juga berkumpul setelah Ashar pada hari Arafah di luar Arafah untuk melakukan do`a bersama (Imam al-Syathiby, 2003: (II) 313).

Dalam perkara ibadah, yang menjadi maqshad al-Syâri adalah ketundukan dan kepatuhan atas apa yang telah ditentukan dalam Alquran dan Sunnah. Maka sukût al-Syari di sini dapat dipahami dengan ketidak bolehan melakukan penambahan ataupun pengurangan atas ibadah yang telah digariskan. Sebab hukum asal dari ibadah adalah mengikuti apa yang telah disyari`atkan Allah Swt dan juga RasulNya. Jika ada penambahan ataupun pengurangan mesti disertakan dengan dalil syara' yang kuat dan jelas sehingga tidak melahirkan keraguan dan kerancuan dalam beribadah.

Dalam al-I'tishâm Imam al-Syâthiby mendefinisikan bid ah dengan:

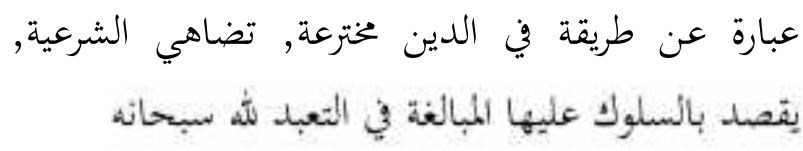

Ungkapan untuk mendeskripsikan sebuah cara ataupun metode yang dibuat-buat dalam agama yang bertentangan dengan nilai agama dan maksud dari (penciptaan cara tersebut) adalah untuk berlebih-lebihan dalam menghambakan diri kepada Allah Swt.(Imam al-Syathiby, t.th.: (I) 43).

Terlarangnya perbuatan bid'ah sehingga amalan ini dibenci dan tertolak, disandarkan kepada Hadis Rasulullah Saw:

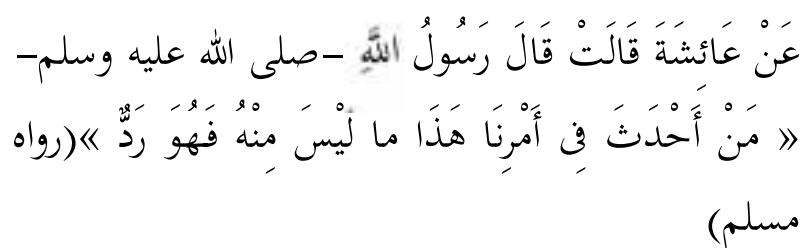

Dari Aisyah ra. ia berkata bahwa Rasulullah Saw bersabda, Siapa yang mengada-ada dalam urusan kami (ajaran Islam) sesuatu yang budak darinya maka ia tertolak. (HR. Muslim) (Musa Syahin, 2002: (VII) 39).

Ibadah merupakan cara yang diperintahkan Allah Swt kepada manusia untuk mengagungkan-Nya dan menghambakan diri kepada-Nya. Oleh sebab itu dalam menentukan bentuk ibadah adalah mutlak hak Allah Swt dan tidak ada andil manusia di dalamnya. Sebab tidak ada seorangpun dari manusia yang bisa mengerti dan memahami hikmah ataupun tujuan disyari’atkannya ibadah oleh Allah Swt. 
Dalam urusan ibadah, manusia hanya tunduk dan patuh menjalankan perintah. Sebab semuanya merupakan ketentuan dari Allah Swt. Selanjutnya, dari setiap apa yang diperintahkan tidak boleh ditambah-tambah ataupun dikurang-kurangi. Dalam sebuah kaedah disebutkan:

$$
\text { اللأصل في العبادات الحظر فلا يشرع منها إلا ما شرعه }
$$

(Hukum) asal dari ibadah adalah terlarang maka tidak boleh dilakukan kecuali apa yang telah disyariatkan oleh Allah Swt dan Rasul-Nya. (Abdurrahman al-Sa'dy, 2002: 72).

Jadi, hukum asal dari ibadah adalah haram ataupun terlarang, sehingga ada dalil yang menerangkan bahwa ibadah tersebut dibolehkan. Jika tidak ditemukan keterangan berupa nash maka yang demikian dinamakan dengan bid ah. Maka dari sini dapat dipahami bahwa tidak boleh berimprovisasi ataupun berinovasi dalam perkara ibadah dengan alasan ketiadaan keterangan hukum dari Allah Swt. Namun semuanya mesti sesuai dengan keterangan yang telah disampaikan oleh Rasulullah Saw.

\section{Sukut al-Syari dalam Pandangan Ulama Lain}

Sukût al-Syâri'menurut Imam alSyathiby, dalam pandangan ulama lain dikenal dengan al-mashlahah al-mursalah. Sebab keduanya berbicara tentang ketiadaan dalil yang eksplisit tentang hukum sebuah perbuatan. Terutama perbuatan yang muncul setalah kenabian. Maka jika dikaji lebih dalam Al-Mashlahah berasal dari kata shalaha (صلح) yang berarti baik, lawan dari kata buruk atau rusak. Al-Bûthy menyebutkan definisi mashlahah dalam dengan:

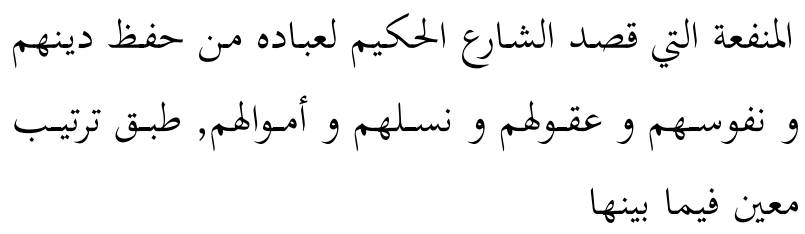

Manfaat yang diinginkan oleh al-Syâri (Allah Swt) bagi hamba-hambanya berupa penjagaan terhadap agama, jiwa, akal, keturunan dan juga harta. Sesuai dengan susunannya." (al-Buthy, 1997: 23)

Setelah menjelaskan maksud dari almashlahah al-mursalah, sekarang penulis akan menghubungkannya dengan konsep sukût al-Syâri yang digagas oleh Imam alSyâthiby. Dari beberapa aspek terdapat kesamaan antara sukût al-Sya 'ri dengan al-mashlahah al-mursalah, yaitu:

1. Sukut al-Syari dan al-mashlahah almursalah sama-sama beranjak dari upaya untuk menjelaskan status hukum pada permasalahan yang tidak memiliki keterangan yang ekplisit dari nash.

2. Sukut al-Syari dan al-mashlahah almursalah sama-sama berpijak dari konsep mashlahah yang terkandung di balik perbuatan.

3. Sukut al-Syari dan al-mashlahah almursalah dalam memberikan kepastian hukum pada sebuah perbuatan yang baru merujuk kepada keglobalan dalil syara'.

Namun, jika dilihat lebih dalam menurut penulis ada beberapa indikator yang menjadikan sukût al-Syâri berbeda dengan al-mashlahah al-mursalah. Indikator inilah yang menjadikan konsep sukût alSyâri yang digagas dan dikembangkan 
oleh Imam al-Syâthiby menjadi khas dalam belantara perkembangan ilmu Ushul Fiqh.

Di antara indikator yang membedakan sukût al-Syâri dengan al-mashlahah almursalah yaitu:

1. Meskipun metode sukût al-Syâri dan almashlahah al-mursalah berpijak dari ketidak adaannya dalil yang ekplisit atas sebuah perbuatan. Namun, sukv̂t al-Syâri lebih menekankan pembacaan terhadap keberadaan dalil atau tidak. Sedangkan pada al-mashlahah almursalah lebih menitikberatkan pada keberadaan maslahat atau tidak yang dikandung oleh sebuah perbuatan.

2. Sukut al-syari mencakup ranah 'ibadah, muàmalah dan 'adah yang tidak memiliki dalil yang ekplisit dalam penetapan hukumnya. Sedangkan alal-mashlahah al-mursalah hanya mencakup pada ranah muamalah dan adah tidak mencakup pada lapangan ibadah.

\section{PENUTUP}

Dari pemaparan di atas dapat dipahami bahwa konsep ijtihad yang dimunculkan oleh Imam al-Syathiby, yang dikenal dengan sukût alSyâri merupakan salah satu cara untuk memberikan kepastian hukum pada perbuatan manusia. Khususnya pada bentuk perbuatan yang muncul setelah kenabian dan tidak memiliki sandaran pasti berupa dalil juz i. Hal inilah yang memotivasi Imam al-Syathiby untuk melakukan penggalian lebih dalam sebagai upaya untuk memahami maqashid al-syariah al-Islamiyah.

Imam al-Syathiby membaginya kepada dua bentuk, pertama perkara muamalah. Dalam bentuk ini, ketiadaan nash pada sebagian perbuatan manusia merupakan bentuk rahmat. Ia menjelaskan bahwa Allah Swt memberikan kelapangan manusia untuk mengembangkan pola interaksinya sebagai upaya mewujudkan kemudahan dan kemashlahatan dalam kehidupan.

Kedua, perkara ibadah. Dalam bentuk ini, tidak boleh seorangpun melakukan perubahan ataupun penambahan dari bentuk ibadah yang telah diajarkan. Sebab tidak ada otoritas manusia dalam melakukan hal tersebut karena hal itu merupakan kuasa Allah Swt. Jika dilakukan maka perbuatan tersebut dikategorikan bidiah dan segala amalan yang dikerjakan akan tertolak.

Demikianlah tulisan singkat ini, semoga dapat menambah ilmu dan wawasan kita. Penulis menyadari masih banyak kekurangan dan berharap masukan yang bersifat konstruktif untuk kebaikan kita semua.

\section{DAFTAR KEPUSTAKAAN}

Ajfan, Muhammad Abu al. 1985. Min Atsâr Fuqahâ' al-Andalus; Fatâwa alSyâthiby. Tunisia. Nahju Louz.

Baghdady, Al-Syaikh al-Imam Syihâbuddin Abu Abdullah Yaqût bin Abdullah al-Hamuwy al-Rûmy al-. 1997. Mu`jam al-Buldân. Beirut. Dâru al-Tsaqâfah.

Buthy, Said Ramadhan al-. 1997. Dhawâbith al-Mashlahah fi al-Syari ah al-Islâmiyah. Beirut: Muassasah alRisalah.

Habib, Muhammad Bakar Isma il. 1427. Maqâshid al-Syari`ah; Ta'shilan wa 
Tafilan. Makkah: Râbithah al-Âlam al-Islâmy.

Khâthib, Lisanuddin al-. 1973. al-Ihâthah fi Akhbâri al-Gharnâthah. Cairo. Maktabah al-Khânjy.

Lâsyin, Mûsa Syâhin. 2002. Fathu alMun 'ìm Syarhi Shahih Muslim. Cairo. Dâru al-Syurûq.

Manzhûr, Ibnu al-. 1992. Lisânu al-Arab. Beirut. Dâru al-Ihyâ' al-Turâts alAraby.

Marâghy, Ahmad Musthafa al-.1946. Tafsir al-Marâghy. Kairo. Maktabah al-Bâby al-Halaby.

Naisabury, al-Syeikh al-Imâm Abi Hasan Ali bin Ahmad al-Wâhidy al-. t.th. Asbâbu al-Nuẑ̂l. Beirut. Âlam alKutûb.

Qurthûby, Abu Abdullah Muhammad bin Ahmad bin Abi Bakar al-. 2006. alJâmi`u li Ahkami al-Qur'ani. Beirut. Muassasah al-Risâlah.
Qusyairy, Muhammad bin Ali bin Wahab al-. 2010. Syarhu al-Arba'in alNawawiyah. Kairo. Dâru al-Salâm.

Sam`any, Al-Imâm Abu Sa`ad Abdul Karim bin Muhammab bin Manshûr al-Taimimy al-. 1984. al-Ansâb. Cairo. Maktabah Ibnu Taimiyah.

Subky, Tâjuddin Abu Nashar Abdullah bin Ali bin Abdu al-Kâfy al-. 1999. Raf' 'u al-Hâjib 'an Mukhtashar Ibnu alHâjib. Beirut. Dâru Âlam li al-Kutûb.

Syathiby, Abu Ishâq Ibrahim bin Musa alLakhmy al-. t.th. al-I tishâm. Riyâdh. Maktabah al-Tauhid. 2003. al-Muwâfaqât fi Ushûli al-Syari ah. Beirut. Daru al-Kutûb alIlmiyah.

Ubaidy, Hammâdy al-. 1996. al-Syâthiby wa Maqâshidu al-Syariah. Beirut. Dâru Qutaibah. 